\title{
Integrated Islamic Curriculum Development in Thematic Learning Against the Formation of Students' Critical Attitude in Islamic Elementary Schools
}

\author{
Shanti Nurhayati ${ }^{1}$, Ana Andriani ${ }^{2}$ \\ $\left\{\underline{\text { nurhayatishanti3@gmail.com }}\right.$, $\underline{\text { ana.andriani@gmail.com }}{ }^{2}$ \} \\ ${ }^{1,2}$ Magister Pendidikan Dasar, Universitas Muhammadiyah Purwokerto
}

\begin{abstract}
The development of an integrated Islamic curriculum is a process of planning and compiling a curriculum by curriculum developers in Islamic schools and this activity is carried out so that the resulting curriculum can be used as teaching material and reference to realize the goals of national education. The development of an integrated Islamic curriculum in Islamic schools is to combine the national curriculum with a distinctive integrated Islamic curriculum. One of the implementation of this development is the formation of students' critical attitudes This study aims to determine: 1) the development of an integrated Islamic curriculum 2) the implementation of integrated Islamic curriculum development in thematic learning and the formation of students' critical attitudes 3) the obstacles faced in its application. The research approach used is qualitative with the case study method. This study will discuss the development of an integrated Islamic curriculum that is applied to thematic learning and its role in forming students' critical attitudes.
\end{abstract}

Keywords: Integrated Islamic Curriculum Development, Thematic Learning, Critical Attitude, Islamic Elementary School

\section{Introducing}

The content of the curriculum in the national education system (schools) under the auspices of the Ministry of National Education emphasizes more on cognitive aspects and weak on other aspects. Curriculum development is needed to realize the goals of national education. One of the 21 st century skills is critical attitude. The formation of students' critical attitudes can be realized through the development of an institution's curriculum. Curriculum development is planning learning opportunities that are intended to lead students towards the desired changes and assess the extent to which these changes have occurred in students[1]. Integrated Islamic schools carry out curriculum development by combining the national curriculum with a unique, integrated Islamic local content curriculum that is full of character building. The author is interested in digging deeper into the implementation of integrated Islamic curriculum development towards the formation of the critical character of students.

The curriculum is an educational program provided by schools, not limited to the field of study and learning activities, but includes everything that can affect the development and personal formation of students in accordance with educational goals which are expected to improve the 
quality of life, which is not only implemented in schools, but also outside of school [1] . The national curriculum used will be adjusted to the needs and conditions of each institution so that there is a need for development. The success of a curriculum referred to in curriculum theory requires a long process, starting from the crystallization of various ideas and ideal concepts about education, formulating curriculum design, preparation of educators and education personnel, as well as facilities and infrastructure, governance of curriculum implementation - including learning and learning assessment. and curriculum [2] . Curriculum development is the process of planning and compiling a curriculum by a curriculum developer and activities carried out so that the resulting curriculum can be used as teaching material and reference to achieve national education goals [3] . Curriculum development in Indonesia cannot be separated from the goals of national education as stated in Law Number 20 concerning the National Education System in 2003 article [2], which states that "National education functions to develop capabilities and shape the character and civilization of the nation. which is useful in the context of developing the intellectual life of the nation, aims to develop the potential of students to become human beings who believe and have faith in God Almighty, have noble character, are healthy, knowledgeable, capable, creative, independent, and become democratic citizens responsibly. [4] Curriculum development in integrated Islamic schools plays a very important role in the description of the integrated concept. The integrated Islamic school curriculum has succeeded in having a significant impact on the learning process that runs in the classroom. [5] The context of curriculum development relates to two things, namely the development of a field of study / course / subject (course); and developing a comprehensive educational curriculum (curriculum). Both (course and curriculum) have a contribution to interconnect, influence each other, and depend on implementation. Thought and research that is in-depth and comprehensive, which in essence is in the form of consideration of factors that must be considered by curriculum developers in developing curricula in educational institutions, both macro and micro [6]

Thematic learning is an effective way to contextualize learning methods. Thematic learning is oriented towards students' concrete learning methods and facilitates students and teachers to get cooperative and interactive learning opportunities in the classroom [6] . Thematic learning in Primary Schools to integrate the dimensions of attitudes, knowledge, and skills into a single unit, combining competences from several basic lessons to be linked to each other so as to strengthen each other, combining the core competencies of each lesson so that each lesson still has its own basic competencies and connects various subjects with the surrounding environment [7]. Thematic learning is oriented to the developmental needs of children, which means rejecting drills as the basis for forming children's knowledge and intellectual structures. When compared with conventional learning, Thematic learning emphasizes active student involvement both cognitive and skill in the learning process.

The principle of "Learning while playing and Learning by doing" is applied in thematic learning [8]. For the implementation of thematic learning, there are several components that need to be discussed first, such as methods, assessment, media, learning steps and the role of the teacher. After that will discuss the steps for preparing thematic learning as well as examples of thematic matrices, syllabus and lesson plans. The methods used in Thematic learning are various so that students do not get bored such as; role playing, field trips, questions and answers, experimentation, singing, bulletin boards, assignments, exhibitions, problem solving, group discussions, observations, exercises, etc [9]. 
The development of students' critical attitudes cannot be separated from the educational process. A critical attitude must be possessed by a person as a form of desire for a good cause. This critical thinking ability requires each student to study a problem based on a different point of view through reasoning which is an explanation of the character of curiosity. Two factors that cause critical thinking to not develop during education are curriculum that is generally designed with a broad target material so that educators are more focused on completing the material and the lack of understanding of teaching methods that can improve critical thinking skills [10]. The results of the development of critical thinking skills will encourage students to be able to obtain information with high credibility. Students can also formulate questions and statements appropriately, be courageous in initiating something, and tolerance of opinion. Students really need critical thinking in academic life to solve various problems in the overall subjects arranged in the curriculum. [11]

Islamic primary schools are part of educational institutions that provide educational services not only in general science but integrated with Islamic values. Islamic education allows a student to lead his life in balance between general science and religious values. Through this approach, students will be able to easily shape their own life in accordance with the values of Islamic teachings that they believe in so that the main personality will be formed, namely Insan Kamil.

Islamic elementary schools that are committed to practicing Islamic values in a learning system which includes not only general lessons but also Islamic religious education which is directly practiced in the teaching and learning process, so that the theory obtained in class can be directly applied in daily life. day. This concept is believed to be able to build quality education by integrating various components and strengths which are expected to be able to give birth to Indonesian people who are competitive and at the same time have high integrity and morality [12]. The curriculum structure of an integrated Islamic school is an integral part of the national education system. Integrated Islamic Schools accept all subjects from the national curriculum. The curriculum prepared by the National Education Standards Agency (BSNP) was later used as the Regulation of the Minister of Education and Culture No. 22 of 2006, there are 8 subjects for Elementary School students plus local content and self-development.

\section{$2 \quad$ Method}

The research approach used is qualitative descriptive and is a case study. Sources of data are taken from informants, places and events, and documents. The results of the study were analyzed using an interactive analysis model. This research uses data collection techniques in the form of interviews, observation, questionnaires and documentation. The research subject is the main source of research data, that is, having data about the variables studied, this research subject will basically produce a conclusion on the research results. In this study, researchers took subjects from the principal, students and parents of students. The operational definition of this research is the development of an integrated Islamic curriculum, thematic learning, critical attitudes and Islamic Primary Schools.

\section{Discussion}

The broader definition of curriculum has characteristics, namely first, in terms of content and activities, it does not only cover the subjects given in the classroom, but includes all activities that can affect the understanding, appreciation, practice, and skills of students in all fields. Second, in terms of the process, it does not only include activities provided by the 
teacher to students, but also specific and directed activities carried out by students. Third, in terms of form, it does not only include forms that are formally stipulated in the curriculum document, but also other forms of activity that are non-formal or invisible. That's as the hidden curriculum [13]

The implementation of the curriculum design applied in the Integrated Islamic Primary School is a curriculum design that is compiled by integrating Islamic values in all school activities including the learning process. The concept of integration with Islamic values will affect the character / morals of students. Integrated Islamic schools have different characteristics from schools or madrasas in general, strengthening is in the form of Islamization in all aspects of educational activities while in school, starting from habituation, extra-curricular and all forms of learning in other classes. Integrated Islamic schools also have a curricular fabric resulting from the unification of general education and religious education, where the dichotomy of the curriculum has been a major problem for Islamic education in Indonesia. [13]

Integrated Islamic schools have quality standards in the formation of student character inside and outside the classroom. Quality assurance at SDIT as an Islamic religion-based school is, of course, quality assurance directed at national education standards combined with Islamic values, namely (1) teaching material standards that contain Islamic nuances,(2) curriculum standards that have the ultimate goal of dedication to Allah, (3) the standard of Muslim educators who are skilled pedagogically and master the law of reading the holy book of the Quran, and (4) the standards of educational institutions characterized by Islam in learning activities and school programs must be Islamic with the objectives of the participants. students capable of knowledge, moral, and have a noble character [14].

Thematic learning combined with the SIT curriculum makes students think critically, actively explore information, discover concepts and scientific principles in a holistic, meaningful, and authentic way [16]. Students are more active in asking questions and responding to information from the teacher. Constraints faced in the application of the Integrated Islamic curriculum development in the thematic learning process and the formation of students' critical attitudes towards teachers who are less consistent in applying them. This inconsistency factor arises because of the limited learning time of teachers who do not prepare the lesson plan maximally, the difficulty of finding references to Islamic material that is relevant to thematic learning. The inability of children to express their desires, feelings and actualize what is within them makes the problems faced by children even greater. So that children need the ability and skills to express the problems they face to others. All these skills can be possessed by students if educators are able to develop learning plans that contain activities that challenge students to think critically in solving problems.

Activities that encourage students to work together and communicate must be visible in every lesson plan they make [15] . Learning is not just transferring knowledge in the form of materials, but learning also sharpens students' critical thinking skills. Critical thinking is a directional and clear process used to solve a problem [16]. Students' inability to think critically can be caused by inappropriate learning strategies. Teachers do not have variation in teaching, it could also be caused by limited facilities and infrastructure[6].

\section{$4 \quad$ Conclusion}


Curriculum development is carried out as an effort to realize the goals of national education. The development of an integrated Islamic curriculum combines the content of the national curriculum.

\section{References}

[1] Bahri S. Pengembangan kurikulum dasar dan tujuannya. Jurnal Ilmiah Islam Futura. 2017 Feb 3;11(1):15-34.

[2] Aryani IK. Napak Tilas Perjalanan Kurikulum 2013 Dan Implikasinya Pada Pendidikan Dasar. Dwija Inspira: Jurnal Pendidikan Multi Perspektif. 2019 Dec 31;2(1):47-64.

[3] Rojii M, Istikomah I, Aulina CN, Fauji I. Desain Kurikulum Sekolah Islam Terpadu (Studi Kasus di SMPIT Insan Kamil Sidoarjo). Al-Tanzim: Jurnal Manajemen Pendidikan Islam. 2019 Oct 29;3(2):49-60.

[4] Ministry of National Education, Law number 20 of 2003 concerning the national edu system,

(Jakarta: 2004)

Pembelajaran. Jakarta, Bumi Aksara, 2011

[6] Sari NA, Yuniastuti Y. Penerapan pembelajaran tematik terpadu di sekolah dasar. Jurnal Pendidikan: Teori, Penelitian, Dan Pengembangan. 2018 Dec 1;3(12):1572-82.

[7] Karli H. Penerapan pembelajaran tematik SD di Indonesia. EduHumaniora| Jurnal Pendidikan Dasar Kampus Cibiru. 2015;2(1), 1-11.

[8] Alawiah AL, Damaianti VS, Kosasih E. PENGEMBANGAN SIKAP KRITIS SISWA DALAM KEGIATAN BERLITERASI DI SEKOLAH. In Seminar Internasional Riksa Bahasa 2019.

[9] Utami B, Saputro S, Ashadi A, Masykuri M, Widoretno S. Critical thinking skills profile of high school students in learning chemistry. InInternational Journal of Science and Applied Science: Conference Series 2017 Aug 14 (Vol. 1, No. 2, pp. 124-130).

[10] Akhmad. Integrated Islamic Primary School Management, J of Educational Sciences, Vol 22, No. 1, 2016, p. 2

[11] Nata, Abudin, Filsafat Pendidikan Islam, Jakarta: Gaya Media Pratama, 2005.

[12] Utami B, Saputro S, Ashadi A, Masykuri M, Widoretno S. Critical thinking skills profile of high school students in learning chemistry. In International Journal of Science and Applied Science: Conference Series 2017 Aug 14 (Vol. 1, No. 2, pp. 124-130).

[13] Rojii M, Istikomah I, Aulina CN, Fauji I. Desain Kurikulum Sekolah Islam Terpadu (Studi Kasus di SMPIT Insan Kamil Sidoarjo). Al-Tanzim: Jurnal Manajemen Pendidikan Islam. 2019 Oct 29;3(2):49-60.

[14] Rachmad Saputra Bagus. Internalization of religious values in quality assurance of integrated Islamic primary schools. Educational Sciences: Journal of Educational Theory and Practice Studies, 2019. Vol. 2, p15

[15] Munawaroh S. Penggunaan media pembelajaran al-qur'an hadis berbantuan whiteboard animation dalam menumbuhkan keterampilan abad-21 di MI Thoriqul Ulum Lamongan (Doctoral dissertation, UIN Sunan Ampel Surabaya). 
[16] Aida TN, Anggoro S, Andriani A. Analisis Berpikir Kritis Siswa Melalui Model POE (Predict-Observe-Explain) di Sekolah Dasar. Jurnal Elementaria Edukasia. 2019;2(2):164-72. 